\title{
Szöke Melinda
}

\section{A Pécsváradi oklevél Scedluc helynevéről*}

1. A Szent István korára visszahamisított Pécsváradi oklevelet (1015), illetve II. Géza átíró oklevelét (1158) a 13. század első felében jegyezhették le, amelyhez egyéb források mellett minden bizonnyal a 11. századi Szent István-kori hiteles alapítólevelet, illetve a század végéről származó összeíró oklevelet is felhasználták. Ezek az oklevelek (a hiteles alapítólevél, illetve az összeíró oklevél) önállóan nem, csak a hamis oklevélbe szerkesztve maradtak fenn. Emiatt nem lehetünk teljesen biztosak a létezésükben, de számos érv szól amellett, hogy a hamis oklevél kiállításakor felhasznált források között a pécsváradi apátság hiteles okmánya, illetőleg az összeíró oklevele is helyet kapott (vö. például GYÖRFFY 1969: 203, KRISTÓ 2000: 317, 320). Az alapítólevél legrégebbi szövegét, azaz a 13. századi hamis oklevelet a 15. század legelejéről fennmaradt többszörös átiratból ismerjük. Az elmondottakat figyelembe véve a Pécsváradi oklevelet a következöképpen datálhatjuk: +1015/+1158 [1220 k.]/1323/1403/PR. (DHA. 1: 67-68).

Ahhoz, hogy a bizonytalan kronológiai státuszú Pécsváradi oklevelet nyelvtörténeti forrásként felhasználhassuk, az alapítólevél szórványait egyenként kell feltárnunk abból a szempontból, hogy az egyes elemek a 11., a 13. vagy a 15 . századi kronológiai réteghez tartoznak-e inkább, azaz az eredeti hiteles oklevélben is szerepeltek már, vagy csupán a hamisítás korában, esetleg a hamis oklevél átírásának korában kerültek bele a szövegbe, illetőleg hang- és helyesírás-történeti jellegzetességeik alapján melyik század nyelvi elemei közé sorolhatjuk őket. ${ }^{1}$

\footnotetext{
* A tanulmány az MTA-DE Magyar Nyelv- és Névtörténeti Kutatócsoport programja keretében és az NKFI 128270. számú pályázat támogatásával készült.

${ }^{1}$ Ha szigorúan vennénk a nyelvtörténeti szempontból lehetséges kronológiai réteg kijelölését, akkor egy negyedik, a 14. századból származó réteggel is számolnunk kellene a Pécsváradi oklevél kapcsán, a 15. század eleji átírást ugyanis megelőzte egy 14. századi (1323-as) is. Véleményem szerint azonban egy ennyire differenciált osztályozás nagyobb mértékben nehezítené meg a szórványok értékelését, mint amennyi haszonnal járna, ezért erre a negyedik rétegre nem leszek tekintettel az oklevél elemzésekor. Legfőbb célom ugyanis az, hogy meghatározzam, mely elemek tartozhatnak a forrásszegény 11 . század kronológia rétegéhez, és melyeknek a lejegyzése mutat a későbbi századokra (vö. SzÖKE 2015: 24).
} 
A Pécsváradi alapítólevél névformái közül GYÖRFFY GYÖRGY kettőt (Sorlogys, Scedluc) az ösmagyar koriak² közé sorolt (1977: 236, 1988: 21, 2001: 99). A vélhetően 11. századi formában szereplő és Sarlós-ként azonosítható Sorlogys helynevet egy korábbi tanulmányomban vizsgáltam meg (SZÖKE 2019), ezúttal pedig a másik, a Scedluc településnevet kívánom nyelvtörténeti módszerekkel elemezni.

A 41 települést mint adományt felsoroló Pécsváradi alapítólevél tizennyolcadikként említi a Scedluc nevüt: „octavadecima Scedluc” (DHA. 1: 74). Az Árpádkori Magyarország történeti földrajza címü munkájában GYÖRFFY GYÖRGY a Baranya megyét feldolgozó részben Szedluk $k^{3}$ utaló címszóval megemlíti ugyan a helyet, de azt a szomszédos Tolna megyébe lokalizálja (Gy. 1: 382). ${ }^{4}$ A Korai magyar helynévszótár mint a Baranya megyei Szedlec település adatát szerepelteti a Scedluc szórványt (KMHsz. 1: 251).

Szedluk $\sim$ Szedlec település nincs sem a mai Tolna (TMFN.), ${ }^{5}$ sem pedig Baranya megyében (BMFN.). Baranyában találunk viszont egy Szellő nevü települést (vö. BMFN. 2: 255-261, FNESz. 2: 550), ami ráadásul a megyének éppen azon a részén helyezkedik el, ahová az alapítólevél birtokfelsorolása alapján a Scedluc névvel jelzett település is jó eséllyel lokalizálható. A mai Szellő Pécsváradtól délre, délkeletre található, ott, ahol a hamis Pécsváradi oklevélben közvetlenül Scedluc után említett települések (Nevegy, Szilágy, Pall, Somló) is fekszenek (DHA. 1: 74, Gy. 1. Baranya megye térképvázlata, BMFN. 2: 257). Minthogy pedig a Pécsváradi alapítólevél és az oklevelek általában a településeket nem önmagukban és véletlenszerüen, hanem birtoktömbökként veszik sorra, a Scedlucként említett helyet is Pécsváradtól délre, délkeletre célszerü keresnünk. Ezek alapján úgy tünik, hogy GYÖRFFY GYÖRGYnek - a fentebb említettnél később írott munkáiban - igaza lehet abban, hogy az oklevélbeli Scedluc a mai Szellö település nevének legkorábbi említése lehet (GYÖRFFY 1977: 236, 1988: 21, DHA. 1: 19, 2001: 99, vö. FNESz. 2: 550).

${ }^{2}$ Ehhez máris érdemes hozzáfüznünk, hogy a 15. századi átiratban ránk maradt hamis oklevélből — amelynek eredeti példánya a 13. században készült, amikor a 11. század eleji alapítólevelet, illetve a 11. század végi összeírást vélhetően bedolgozták a latin szövegbe — nyelvi szempontból semmi esetre sem lehet a honfoglalást megelőző ősmagyar korra, legfeljebb csak a 11. század elejére következtetni.

${ }^{3}$ Sörös Pongrác (1905: 865), Gállos Ferenc (1988: 45) és Kiss Gergely (1999: 51) Szedlok névvel utal a településre.

${ }^{4}$ A kötetekhez készült egyik cédulára (ahol Baranya, Tolna és Somogy megye is szerepel kérdőjellel) ezt írta GYÖRFFY GYÖRGY: „nem lehet Szellő, mert Szántó - $\gamma$-t nem tüntet fel”. Ezúton is köszönöm Nógrády Árpád szíves segítségét, hogy megtekinthettem a településre vonatkozó cédulákat.

${ }^{5}$ Az alapítólevél több Tolna megyei települést is említ, de mindegyik távol esik a szövegben a Scedluc néven (tizennyolcadikként) rögzítettől: Zomba harmadik településként, Szekszárd negyedikként (DHA. 1: 73, 515, 505), Sólyag pedig harminckilencedikként szerepel (DHA. 1: 75, 506). 
A településnév további adatai: +1015/+1158//XV.: Sedluth, +1015/+1158/ /XVII.: Sedlucz, +1015/+1158//XVIII.: Sedluz (DHA. 1: 74), +1158//1403/PR.: Scedluc (Vat. I/4: 574), 1564: Szellÿo (HORVÁTH-TIMÁr 1973: 77), 1710 k.: Szehluh (REUTER 1969-1970: 148, BMFN. 2: 255: 1716 k.), 1773 (BMFN. 2: 256), 1804 (REUTER 1969-1970: 148): Szellö.

2. GYÖRFFY GYÖRGY a történeti földrajz első kötetének megjelenése után közel egy évtizeddel, az Árpád-kori szolgálónépekről írt tanulmányában említi először, hogy Szellő falu neve talán korai szőlőtelepítésre utalhat (1972: 278). Pár évvel később a Szent István királyról írott monográfiájában fejti ki részletesen, hogy a Pécsváradi alapítólevél — itt már [szedlük]-ként olvasott — szórványa a mai Baranya megyei Szellő falut nevezi meg. A helynevet nem a szél $\sim$ szellö lexémára vezeti vissza, hanem a bolgár-török eredetü szölő szavunkra (vö. csuv. *śidläk *śidlä $\gamma>$ magy. *sidlä $\gamma$, TESz., LIGETI 1986: 29), amelynek korai alakját ${ }^{6}$ látja megjelenni az elemzett helynévben (1977: 236, vö. 1988: 21, DHA. 1: 19, 2001: 99).

A település nevének a magyar szél szellő szóból való esetlegesen felmerülö magyarázatát nyelvtörténeti és névrendszertani okokból is szinte teljes bizonyossággal elvethetjük. A levegőmozgás jelentésủ szél szavunk csuvasos jellegü ótö-

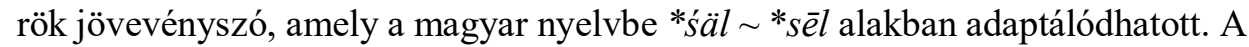
szellö ennek a szónak a magyarban alakult kicsinyítő képzős származéka (TESz., EWUng., WOT.). Egy, a török eredetü szél szóra visszavezethetö helynévnek tehát nehezen képzelhető el a Pécsváradi oklevélben szereplő [szedlük $\sim$ szedlüc] formája. Nem támogatja a névnek ezt az eredeztetését az sem, hogy szél lexémát találunk ugyan a helynevekben, fóként a nevek utótagjaként szerepelve, de ezekben a 'vminek a széle' jelentésü szél mint földrajzi köznév ismerhető fel: például Nagy-szél (1257: „hinc exit virgultum ad locum qui Nogscel dicitur”, Ok1Sz. 905) és Kender-szél (1325: „terrarum arabilium Kendur Zeel nuncupatarum”, OklSz. 905). A Szél önmagában is megjelenik helynévként, településnévként (vö. 1327: Zel, Gy. 4: 297), de ebben is inkább a 'vminek a széle' jelentéstartalom tehető fel. Csak néhány névalak (vö. WOT. szél) esetében vetődhet fel több más lehetőség mellett a légmozgásra utaló motiváció: például a képzős formát mutató Baranya megyei Szeles település neve (1181: Zeles, Gy. 1: 397) tartozhat ide (az említett nevek magyarázatához lásd még a FNESz. Drágszél, Szélgyöp, Szélmezö, Szélszeg, Széltarló, Temenceszél szócikkeit). ${ }^{7}$

\footnotetext{
${ }^{6}$ GYÖRFFY GYÖRGY szerint a lexéma szedlügh formában adaptálódhatott a nyelvünkbe (vö. 1977: 236): $g h$-val jelölve vélhetően $\gamma$-re utalt, tehát bizonyára szedlüy átvevő alakra gondolhatott (vö. DHA. 1: 19).

${ }^{7}$ Hegynevek esetében ugyanakkor légmozgásra való utalással nagyobb eséllyel kell számolnunk (vö. Kiss L. 1999: 129, TÓTH V. 2001b: 64, RESZEGi 2011: 131-132): lásd például Szeles-domb 'huzatos hely' (HeMFN. 1: 35, Kiss L. 1999: 129), Szél-hegy 'nagyon széljárta hely' (HeMFN. 1:
} 
2.1. A természeti környezet egy jellemző körülményére, az ott lévő növényzetre utaló településnevek ugyanakkor gazdag elemszámú csoportját alkotják az ómagyar kori településneveknek. A mintegy 1000 ómagyar kori növénynévi alapú településnévre épülő vizsgálatában GALLASY MAGDOLNA száznál is több növény nevét azonosította, közöttük ráadásul az alma és az éger után a szölö jelenik meg a leggyakrabban településnevek lexémájaként (1989: 86-87). Korán felmerült a szakirodalomban, hogy ezeknek a neveknek a nagy része nem közvetlenül növénynévböl származik, hanem egy vele alakilag azonos víznévből, azaz a Füzes-féle nevek esetleg egy növénynév > víznév > településnév többszörös metonímia révén jöhettek létre (vö. KNIEZSA 1943-1944/2001: 15). A víznévi előzmény azonban leginkább olyankor vethető fel, amikor a helységnevekben vízinövények nevei fedezhetők fel (BENKÖ 1947: 260). A Baranya megyei településsel esetleg összefüggésbe hozható alapnév (tehát például víznév, hegynév vagy erdőnév) nem adatolható a forrásokból, ${ }^{8}$ és tekintve hogy a szőlő nem vízinövény, a vizsgált településnév — amennyiben valóban a szölő szóból magyarázható — feltehetőleg nem lokális viszony kifejezésére szolgál, hanem közvetlenül a település növényzetére, esetleg az ott végzett tevékenységre, a szőlőmüvelésre utal (vö. HOFFMANN-RÁCZ-TÓTH 2018: 331, 335).

Az egyház- és államszervezés idején a szőlőmüvelés egyre nagyobb teret nyert Magyarországon, jelentőségét emelte, hogy az egyházi közösségek mindennapi életéhez - például a keresztény liturgia miatt — elengedhetetlen volt a bor. Szent Benedek Regulájában azt találjuk továbbá, hogy minden bencés szerzetesnek jár naponta minimum egy hemina (három deciliter) bor (vö. SOLYMOSI 1998: 17, 2012: 312). A környék természetföldrajzi viszonyairól, a szőlőmüvelés lehetőségeiről a hamis Pécsváradi oklevélből is szerezhetünk információt: a szolgálónépekről szóló oklevélrész például említ 110 szőlőművest $^{9}$ („,ministris, qui serviunt [...] vinitoribus CX”, DHA. 1: 72), ami azt jelzi, hogy szőlö is volt az apátság, azaz Pécsvárad környékén. Baranya megye Árpád-kori történeti földrajzi leírása is arról tájékoztat, hogy ,a hegyek D-i lejtőin Pécs-Pécsvárad vonalában, Harkány és Villány, továbbá Baranyavár és Köszeg között a szőlőmüvelés volt az egyik fő termelési ág" (Gy. 1: 260). A Pécsváradtól délre fekvő Szellő település

160, KISS L. 1999: 129), ahogyan más időjárási körülmények is kifejeződnek e helynévfajta egyedeiben: pl. Árnyék-mál (Gy. 2: 208, 310, Reszegi 2011: 131), Fagyos-oldal (SzABÓ T. 1942: 12, KISS L. 1999: 129). Azt is érdemes ugyanakkor kiemelnünk, hogy a középkori hegynevekröl írt monográfiájában RESZEGI KATALIN egyetlen ide vonható, a szél 'légáramlat' köznévvel kapcsolatba hozható példát sem említ (2011).

${ }^{8}$ Ez még önmagában persze nem jelenti azt, hogy nem is léteztek ilyen nevü helyek, pusztán adatokkal nem tudjuk igazolni ezt a lehetőséget.

${ }^{9}$ A nagyszámú szőlőműves adományozását, illetve azt, hogy a szolgálónépek felsorolása elején említik őket, GÁLlos FERENC a hamisítással kapcsolja össze (2001: 123). 
határában lévő nevek, illetve denotátumaik tanúsága alapján a szőlőtermelés a 20. században is virágzott a településen (Erdö-szöllö, Āsó-szöllök ajja, BMFN. 2: 260). ${ }^{10}$ A település egykori és mai természeti környezete egyaránt alátámasztja tehát a Scedluc névadat GYÖRFFY-féle, a szölő közszóval összefüggő értelmezését.

2.2. A szölő növénynévnek egyes vidékekröl (éppen a Baranya megyével szomszédos Tolna megye déli részéről is) adatolható a település mai nevével azonos szellő formája is (MTsz. 2: 599, vö. WOT.). ${ }^{11}$ Amennyiben az elemzett név valóban növénynévi eredetü, úgy a település mai nevében a szölö közszó tájnyelvi változata fedezhető fel. MUNKÁCSI BERNÁT a szölö növénynév egykori hangzásáról szólva szintén említ a mai helynévhez hasonló tájnyelvi (szillé, széllé, széllö) alakokat (1882: 60-61).

A szölő közszó szócikkében a TESz. (3: 794), az EWUng. (2: 1455), illetve a WOT. (2: 818-822) sem szerepelteti a Pécsváradi oklevél adatát, ${ }^{12}$ hanem a Garamszentbenedeki alapítólevél Szölös helynevét (1075/+1124/+1217: Sceulleus, DHA. 1: 213, 214) idézik első előfordulásként.

A szölő a csuvasos jellegü ótörök jövevényszavaink közé tartozik (BÁRCZI 1958a: 77, BENKÖ 1967: 282, ZSILINSZKY 2003: 202, GERSTNER 2018a: 252), a jelentése a mainál ('gyümölcsként fogyasztott és bor késztésére használt, ősszel érö fürtös bogyótermés') általánosabb 'bogyó' volt (vö. TESz. 3: 794, WOT. 2: 818-822). BERTA ÁRPÁD - a korai török jövevényszavainkról RÓNA-TAS ANDRÁSsal együtt készített impozáns kötet (a WOT.) munkálatai során — úgy látta, hogy a szölö növénynevet nem kellően indokolt a biztos török etimológiájú szavaink közé sorolni. Véleménye szerint a legnagyobb problémát az okozza, hogy a közös eredetre visszavezetett szavak nem kétséget kizáróan mutatnak közös etimonra (2005: 73-75). Az addigi eredeztetés helyett sokkal inkább a szölö belső magyar fejlemény voltát tartja elképzelhetőnek, azaz egy régi magyar $s z o ̈ v, s z o ̈ l$, szöll ige -ö képzős igenévi származékaként tekint rá, és a jelentését a növény szövevényes, kusza indázatára vezeti vissza (i. m. 76). A hat évvel később megjelent kézikönyvben ugyanakkor ennek a BERTA-féle elképzelésnek a szemantikai hátterét problematikusnak minősíti RÓNA-TAS ANDRÁS, s a szölö-t török eredetüként veszi számba (WOT. 2: 822).

${ }^{10}$ A 20. század második felének helynévgyűjteményét közreadó BMFN. arról tájékoztat, hogy az említett helyek mellett a környéken vannak olyan szőlötermő vidékek is, amelyeknek a nevében ez a sajátosság nem tükröződik: pl. Assó-högy (BMFN. 2: 260).

${ }^{11} \mathrm{Az}$ Új magyar tájszótárban, illetve A magyar nyelvjárások atlaszában a szőlő tájnyelvi alakjai között nem szerepel a szellö (ÚMTsz., MNyA., vö. FKnT.).

${ }^{12}$ A TESz. séd szócikkében azonban feltünik a Pécsváradi oklevél Scedluc adata is (3: 506). A téves lexikális azonosítást mutatja, hogy ezt az adatot az EWUng. szerkesztői már nem szerepeltetik a séd szócikkében (vö. Holler 2009: 23). 
A magyar szót sokáig a csuvas alakból (vö. csuv. śílla 'bogyó') szabályosan következő őstör. *jidläk *yidläk-ra vezették vissza, és közvetlen előzményének

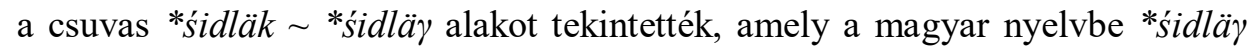
formában adaptálódhatott (vö. például GOMBOCZ 1907: 358, 1924: 63, HORGER 1912: 453, BÁRCZI 1958b: 104, TESz. 3: 794, LIGETI 1986: 29). A szölő szónak ezt a származtatását LIGETI LAJOS a török nyelvtörténet oldaláról cáfolja, nem tartja ugyanis elképzelhetőnek azt, hogy amíg a szókezdő hang a középcsuvas normáihoz igazodott, addig a szóbelseji $d$ változatlanul megőrizte volna őstörök jellegét. Az östörök *yidläk szóból kiindulva a magyar szölő közvetlen forrásaként csak egy *sísläk, esetleg *sirläk alakot tehetnénk fel, LIGETI szerint ezek azonban nehezen egyeztethetők össze a szölö korai Sceuleus-féle származékadataival (vö. ehhez még GOMBOCZ 1906: 145). Megoldásként LIGETI azt javasolja, hogy a szőlő szót magyarázva az őstörök *yigläk-ből kikövetkeztethető középcsuvas *sizläk alakból induljunk ki (1986: 29, 79, 294). LIGETI elképzelését részben a WOT. szerkesztöi is elfogadták: a szölö lexéma előzményeként a keleti ótörök *yeglek $\left(>*^{*}\right.$ yelek) ${ }^{13}$ alakot szerepeltetik, de közvetlen előzményként a

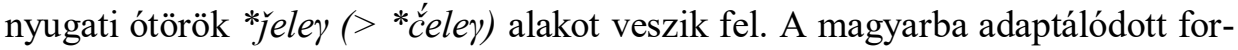

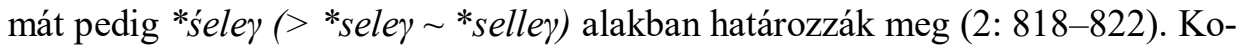
rábban a TESz. a magyarba került csuvas alakként szintén a *śilä (esetleg *śidlä $\gamma)^{14}$ formát rekonstruálta (3: 794), az EWUng.-ban azonban a szó közvetlen előzményeként a LIGETInél látható *śi $l a ̈ k$ szerepel (2: 1455).

A WOT.-ban olvasható *seley alakból a korai Sceuleus, illetőleg Zeuleus-féle (további Szőlő, Szölős adatokhoz lásd KMHsz. 1: 268, OklSz. 938-939, ÉGETŐ 1980: 74-75) származékok (vagyis a szölő alapszó) szabályos hangváltozásokkal (a szóvégi $\gamma$ vokalizációjával, a diftongus monoftongizációjával, az elsőszótagi magánhangzó labializációjával) levezethetők: *śeley > szëlëü (vö. pl. 1193: Celeu, OklSz.) > szölö (pl. 1210: Sceuleus, OklSz.). A szó belseji dl mássalhangzó-kapcsolat miatt a Pécsváradi alapítólevél Scedluc neve viszont ebbe a hangváltozási folyamatba nem illeszthető be (még egy lehetséges [szëdlü $\gamma$ ] hangalak esetén sem).

2.3. A Szölős nevek egy jelentős része vélhetően nem közvetlenül növénynévből alakult ugyan, hanem a 'szőlőmüvelö' jelentésủ foglalkozásnévből (vö. HoFFMANN-RÁCZ-TÓTH 2018: 285), de oklevélbeli előfordulásaikat ettől függetlenül felhasználhatjuk a szőlő lexéma egykori alakváltozatainak a feltérképezéséhez is, hiszen a foglalkozásnév, amiből a településnevek alakultak, a növény nevéből

${ }^{13}$ A WOT-ban szereplő *yeglek a magánhangzók kivételével megegyezik a LIGETInél szereplő *yigläk alakkal (vö. 1986: 29, 79, 294).

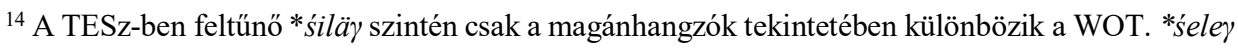
alakjától. 
származik. GYÖRFFY GYÖRGY Az Árpád-kori Magyarország történeti földrajza (Gy.), illetve CSÁNKI DEZSŐ Magyarország történelmi földrajza a Hunyadiak korában (Cs.) címü munkájának köteteit átvizsgálva azt találjuk, hogy egyedül a Bars megyei Szölös neve olvasható $l l$-s formában (Sceulleus), a többi adatban $l$-t találunk. ${ }^{15}$ A Sceulleus formát a Garamszentbenedeki oklevél (1075/+1124/+1217) tartalmazza két ízben. ${ }^{16}$ A szölő szavunkból közvetlenül vagy közvetve alakult helyneveink között — a Pécsváradi oklevél (1015) Scedluc neve után — az interpolált Garamszentbenedeki oklevél hiteles 11. századi rétegéhez tartozó Sceulleus tekinthető az első (1075) ismert előfordulásnak. A következő hiteles, eredeti oklevélben fennmaradt ${ }^{17}$ Szölös adat csak a 12. század közepéröl való: 1156: Sceuleus (Gy. 4: 471). Ezt követően a szóbelseji mássalhangzót tekintve az összes előfordulás hasonló képet mutat.

Az interpolált oklevelek hiteles részében található helynevek nyelvtörténeti forrásértékét éppúgy nehéz meghatározni, mint a hozzátoldott részben szereplökét, az interpoláció korának nyelvi sajátosságai ugyanis a kiegészített oklevélben már megtalálható nevek újbóli lejegyzésében is megmutatkozhattak (vö. SzÖKE 2015: 56-60). Az átnézett nagyszámú adat alapján azonban úgy tünik, hogy az interpolált Garamszentbenedeki oklevél 13. századi (DHA. 1: 212) keletkezésekor (illetve a megelőző és a következő évszázadban) a szölő növénynévben rövid $l$ szerepelt, ezért az alapítólevél Sceulleus nevének lejegyzését a szóbelseji mássalhangzó tekintetében jó esélyekkel köthetjük a 11. századhoz (1075). Felvetődhet tehát, hogy a szölö szavunknak esetleg az $l l$-s (és nem az $l$-s) volt az elsődleges alakváltozata. A növénynévben az $l>l l$ (másodlagos) nyúlása a 15. századtól kezdődően jelentkezik (OklSz. 938-942, KoCÁN 2020: 331-335).

A szölö szavunkat tartalmazó történeti helynevek adatsorába egy $d l>l l(>l)$ (1015: Scedluc > 1075: Sceulleus > 1168: Scevlevs) változást feltételezve az elemzett név is beilleszthető (vö. GOMBOCZ 1907: 358, KARA 1912: 221, NÉMETH 1912: 452, BENKÖ 1953: 52, K. PALLÓ 1959: 250, TESz. 3: 794). HORGER ANTAL — a Pécsváradi oklevélből, illetőleg a Garamszentbenedeki oklevélből származó példákat feltehetően nem ismerve - a 20. század elején nem kérdőjelezi meg, hogy a magyarba átkerült alak a *sidlä $\gamma$ lehetett, csak a mai szölö-nek az ócsuvas etimonból való fejlődését látja problémásnak, abból ugyanis törvényszerüen szëllő fejlödött volna, de a legrégebbi nyelvemlékeinkben ezzel szemben

\footnotetext{
${ }^{15}$ Ezt egyéb források (OklSz. 938-942, ÉGETő 1980: 74-75) adatai is megerősítik.

${ }^{16}$ A Bars megyei település későbbi említéseiben viszont már szintén $l$ található (SzŐKE 2015: 198). A Sceulleus két előfordulása közül az egyik a 11. századi oklevélben is benne lehetett, a másik viszont csak a 13. századi interpoláció során került bele a szövegbe (i. m. 44).

${ }^{17}$ Van egy adat a 12. század első feléböl is, de ez csak 15. századi többszörös átiratban maradt fenn: 1113/1246/1410: Zoulous (Gy. 4: 471).
} 
szélé, szélö, szölő formákat találunk. A $d l>l l(>l)$ változást, amit e szóalak kapcsán néhány évvel korábbi munkájában még feltételezett (1909: 400), ekkor már valószínútlennek gondolta (1912: 453).

A $d l>l l$ változás a korábban említett lehetséges csuvas alakok közül a *sidlä létjogosultságát támogathatja meg. A magyar nyelvbe adaptálódott lexéma szóvégi spiránsa a vokalizálódást követően a megelőző magánhangzóval kettőshangzót alkotva monoftongizálódott (BÁRCZI 1958b: 134, E. ABAFFY 2003: 302, GERSTNER 2018b: 113). ${ }^{18}$

A környék természeti adottságairól, illetve a helynévröl mondottakat összegezve a Pécsváradi alapítólevél Scedluc nevét a mai Baranya megyei Szellö-vel azonosíthatjuk, ami a szölö növénynévböl származik. Ez azt is jelenti egyúttal, hogy a Scedluc név is (részben) a Pécsváradi alapítólevél 11. századi nyelvtörténeti forrásértékü elemei közé sorolható a korábban elemzett Sorlogys-sal együtt. A szóbelseji $d l$ mellett a szó végén megjelenő mássalhangzó szintén a 11. század elejére mutat. A spiráns általános $h$ jele (vö. KOROMPAY 2003: 285, 2018: 87) helyett itt az ebben a hangértékben ritkább $c$ szerepel (BÁRCZI 1958b: 122). ${ }^{19}$ Valószínủ ugyanakkor, hogy a Scedluc lejegyzése mégsem minden tekintetben a feltehető 11. századi eredeti formát tükrözi: erre mutat az $s z$ hang $s c$ jele vagy a spiráns előtti második szótagbeli, vélhetően $\ddot{o}$ hangot jelölő $u$ betű is. ${ }^{20}$

2.4. A Pécsváradi alapítólevél egy 17. századi és egy 18. századi átiratában az elemzett névhez igen hasonló alakok (Sedlucz és Sedluz) tünnek fel (DHA. 1: 74), miközben a 16. században más forrásokból Szellö település neve már Szellÿo (HORVÁTH-TIMÁR 1973: 77, vö. GYÖRFFY 1972: 278). A 17. századi, illetve a 18. századi iratok előzményéül nem I. Károly 1323. évi oklevele, hanem II. András 1228. évi okmánya szolgált. Az 1220 környékén hamisított oklevelet egymástól függetlenül többen is átírták, de ezek közül az 1323. évi I. Károly-féle változat maradt fenn a legkorábbról, ezért alapvetően ezt a változatot használjuk a nyelvtörténeti elemzéseinkhez (vö. DHA. 1: 65). Az a körülmény, hogy az 1228. évi oklevelet átíró kései okmányok a névalakot szinte változtatás nélkül az alapítólevél

${ }^{18} \mathrm{Az}$ itt bemutatott folyamattal nem egyeztethető ugyan össze, de a - $d$ - nélküli feltehető török előzmények miatt fontos megemlítenünk, hogy a tulajdonnevek körében az $l l>d l$ elhasonulásos folyamatra is találunk példát: például Villám > Vidlám szőlőhegy (KISS L. 1995: 9, FNESz. 2: 762).

${ }^{19}$ Az oklevél Sorlogys nevében $g$ jelöli ezt a hangot (DHA. 1: 75, SzÖKE 2019: 94). További $c$-s

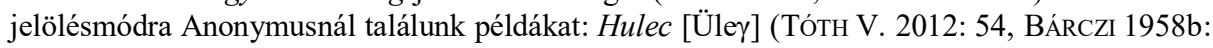
111).

${ }^{20}$ A 11. századra vonatkoztatható okmányok szélesebb körü feltárása után érdemes lehet a két kor hangjelölését és -állapotát tükröző szórványok csoportjába besorolt helyneveket újra megvizsgálnunk. Nem zárható ki ugyanis, hogy bizonyos hangjelölési módokat korábban azért soroltak a későbbi századokhoz, mert a helyesírás-történeti vizsgálatokba a 11. századból csak meglehetősen csekély számú oklevelet vontak be. 
általunk vizsgált szövegében megtalálható formában jegyezték le, szintén arra utalhat, hogy ez a névalak az alapítólevél egy korai változatából származik. ${ }^{21}$

3. Az Abaúj-Csongrád vármegyék korai ómagyar kori névanyagát tartalmazó KMHsz. 1.-ben két Szedlec nevü település szerepel: az itt elemzett Baranya megyei mellett egy Abaúj megyei település ${ }^{22}$ tartozik ide (KMHsz. 1: 251). Ez utóbbinak csak a 14. század elejéről ismerjük az első adatait, ezek viszont nagy hasonlóságot mutatnak az alapítólevél névformájával: 1323, 1347: Zedlech, 1323/1390: Scedluch (Gy. 1: 144, KMHsz. 1: 251). Ez azonban csak véletlen egybeesés, mivel az etimológiai szakirodalom szerint ez az abaúji településnév egy szláv helynévre vezethető vissza (vö. pl. cseh, szlk. Sedlice), s a magyarba a név *Sedlce 'kis falu, falucska' > *Sedlec formában adaptálódhatott (TÓTH V. 2001a: 136, FNESz. 2: 538).

A szláv helynév alapja a szláv sedlo, selo 'ülés, telepedés, falu' jelentésű szó (ŠMILAUER 1970: 158-159). ${ }^{23}$ A Baranya megye földrajzi nevei kötet a településnévnek a 18. század elejéről idézve a legrégebbi előfordulását (1716 k.: Szehluh) ugyancsak felveti a szláv, itt konkrétan a szerb-horvát eredet lehetőségét. Egy ilyen származtatás mellett a mai Szellö név a szellö fönévhez való hasonulás eredményeként jöhetett létre (BMFN. 2: 256).

Az alaki hasonlóság (Scedluc - Scedluch), illetve a környéken található szláv helynevek alapján (vö. például Nógrád, FNESz. 2: 242, Szajk, FNESz. 2: 512) elképzelhető ugyan, hogy a Pécsváradi alapítólevél szórványa az abaúji Szedleccel azonos etimológiai háttérrel jellemezhető, s az oklevél egy [szedlüc] hangalakú nevet rögzített, úgy látom azonban, hogy jóval több érv szól e település nevének a szölö növénynévből való származtatása mellett. A fentebb mondottak ezt még akkor is alátámasztják, ha a nagyszámú Szölös település mellett egyébként Szölö nevüt alig ismerünk. Hont megyében van például egy Szölö (1324: Zeuleu, Gy. 3: 255), de a korábbi adatai ennek a településnek szintén Szölős formájúak. ${ }^{24}$

${ }^{21}$ A Sorlogys ( > Sarlós) név kapcsán is azt tapasztaltam, hogy a 17. és 18. századi átiratok nagyfokú hasonlóságot mutatnak az alapítólevél általunk vizsgált 15. századi változatával (vö. SzÖKE 2019: 93).

${ }^{22}$ Ma Reste település határának helynevei között találjuk meg az egykori Szedlec település nevét (Gy. 1: 144).

${ }^{23}$ BorovszKy SAMU (1894: 80), majd az ö nyomán VIRÁGH RÓZSA (1931: 79) több helynevet (Szelezsán, Szelnica, Szelec, Szelecske, Szelcsák, Szelcsova, Szeleste, Szelestény, Szelistye, Szelény, Szeli, Szele), köztük a Szellő nevet is erre a szláv szóra vezeti vissza.

${ }^{24}$ A kérdés megoldásához nem visz ugyan közelebb minket, mégis fontos szót ejtenünk arról, hogy KENYHERCZ RÓBERT a témánkba vágó névpáron mutatta be az eredeti oklevelek és átiratok közötti viszony egyik jellemző sajátosságát. A Szepes megyei Szedlicska nevü földterület kapcsán az egyik átírt oklevélnek (1290/1313: Zedlichke) fennmaradt az eredetije (1290: Scellyske) is. Sokáig az eredeti 1290. évi oklevél Szöllőské-nek olvasott szórványát tartották helyesnek az átiratban szereplö Szedlicská-val szemben. KENYHERCZ RÓBERT viszont meggyőzően bizonyítja 
Az abaúji Szedlec és a Baranya megyei Szellö példája ilyen módon azt is jól mutatja, hogy a korai okleveles adatok azonos lejegyzésü formái (Scedluch és Scedluc) mögött is rejtőzhet különböző etimológiai előzmény.

4. A fent leírtak fontos tanulságaként arra kell rámutatnunk, hogy a Scedluc szórvány — a korábban elemzett Sorlogys mellett — helynévtörténeti és nyelvtörténeti szempontból egyaránt a Pécsváradi oklevél korai rétegéhez tartozik. Ezek a névalakok hang- és helyesírás-történeti szempontból (részben) a 11. század elejére (Szent István korára) mutatnak, azaz támogató érvként szolgálhatnak az 1015. évi hiteles oklevél létezése mellett is. A bizonytalan kronológiai státuszú Pécsváradi oklevél Scedluc adata és a Garamszentbenedeki alapítólevél Sceulleus szórványa jelentik tehát az itt mondottak értelmében a szőlő növénynévnek a legkorábbi előfordulásait.

\section{Irodalom}

E. ABAFFy ERZSÉBET 2003. Az ómagyar kor. Hangtörténet. In: KISS JENÖ-PUSZTAI FERENC szerk. Magyar nyelvtörténet. Budapest, Osiris Kiadó. 301-351.

BÁRCZI GÉZA 1958a. A magyar szókincs eredete. Második, bővített kiadás. Budapest, Tankönyvkiadó.

BÁRCZI GÉZA 1958b. Magyar hangtörténet. Második, bővített kiadás. Budapest, Tankönyvkiadó.

BENKÖ LORÁND 1947. Víz- és helységneveink viszonyához. Magyar Nyelv 43: 259263.

BENKÖ LORÁND 1953. Hangtani tanulmányok a magyar kettőshangzók köréböl. Nyelvtudományi Közlemények 54: 37-62.

BENKÖ LORÁND 1967. A magyar szókészlet eredete. In: BÁRCZI GÉZA-BENKÖ LORÁND-BERRÁR JOLÁN, A magyar nyelv története. Budapest, Nemzeti Tankönyvkiadó. 259-351.

BERTA ÁRPÁD 2005. Szőlö. In: FelFöldI SzABOLCS szerk. Abhivaadana. Tanulmányok a hatvanéves Wojtilla Gyula tiszteletére. Szeged, Szegedi Egyetem, Ókortörténeti Tanszék. 73-80.

BMFN. = PESTI JÁNOS szerk. 1982. Baranya megye földrajzi nevei I-II. Pécs, Baranya Megyei Levéltár.

BOROVSZKY SAMU 1894. A honfoglalás története. A müvelt közönség számára. Budapest, Franklin Társulat.

Cs. = CSÁNKI DEZSÖ 1890-1913. Magyarország történelmi földrajza a Hunyadiak korában I-III., V. Budapest, Magyar Tudományos Akadémia.

egyrészt azt, hogy a Szöllőske olvasat helyett sokkal valószínübb a Szelliska, másrészt pedig azt, hogy a romlott formát ezúttal az eredeti oklevél tartalmazhatja, amelyet az átírás során felismertek és javítottak (KENYHERCZ 2016: 22-25). 
DHA. $=$ GYÖRFFY GYÖRGY szerk. 1992. Diplomata Hungariae Antiquissima. Vol. I. Budapest, Akadémiai Kiadó.

ÉGETŐ MELINDA 1980. Középkori szőlőművelésünk kérdéshez. Ethnographia 91: 53-78.

EWUng. = Etymologisches Wörterbuch Ungarischen I-II. Föszerk. BENKÖ LORÁND. Budapest, Akadémiai Kiadó. 1993-1995.

FKnT. = BÁBA BARBARA-NEMES MAGDOLNA 2014. Magyar földrajzi köznevek tára. A Magyar Névarchívum Kiadványai 32. Debrecen. Debreceni Egyetemi Kiadó.

FNESz. = KISS LAJOS 1988. Földrajzi nevek etimológiai szótára I-II. Negyedik, bövített és javított kiadás. Budapest, Akadémiai Kiadó.

I. GALlASY MAGDOLNA 1989. Növénynévi alapú régi településneveink. In: BALOGH LAJOS-ÖRDÖG FERENC szerk. Névtudomány és müvelödéstörténet. A IV. Magyar Névtudományi Konferencia elöadásai Pais Dezsö születésének 100. évfordulóján. A Magyar Nyelvtudományi Társaság Kiadványai 183. Budapest. 83-93.

Gállos FerenC-Gállos Orsolya 1988. Fejezetek Pécsvárad történetéböl. Pécs, Baranya Megyei Múzeumok Igazgatósága.

GÁllos FerenC-GÁLlos ORSOLYA 2001. Pécsvárad bencés apátsága és települése a középkorban. In: FÜZESI MIKLÓS szerk. Pécsvárad. Pécsvárad, Pécsvárad város Önkormányzata. 103-197.

GERSTNER KÁROly 2018a. Szókészlettörténet. In: KisS JenÖ-PuszTAi FERENC szerk. A magyar nyelvtörténet kézikönyve. Budapest, Tinta Könyvkiadó. 249-270.

GerstNer KÁROLY 2018b. Hangtörténet. In: Kiss JenÖ-PuSZTAI FERENC szerk. $A$ magyar nyelvtörténet kézikönyve. Budapest, Tinta Könyvkiadó. 103-128.

Gombocz Zoltán 1906. A bor. Magyar Nyelv 2: 145-152.

GOMBOCZ ZoLTÁN 1907. Régi török jövevényszavaink. Magyar Nyelv 3: 357-370.

Gombocz Zoltán 1924. Sömör. Magyar Nyelv 20: 60-63.

Gy. = GYÖRFFY GYÖRGY 1963-1998. Az Árpád-kori Magyarország történeti földrajza $I-I V$. Budapest, Akadémiai Kiadó.

GYÖRFFY GYÖRGY 1969. A magyar egyházszervezés kezdeteiröl újabb forráskritikai vizsgálatok alapján. MTA Filozófiai és Történettudományok Osztályának Közleményei 18: 199-225.

GYÖRFFY GYÖRGY 1972. Az Árpád-kori szolgálónépek kérdéséhez. Történelmi Szemle 15: 261-320.

GYÖRFFY GYÖRGY 1977. István király és müve. Budapest, Gondolat.

GYÖRFFY GYÖRGY 1988. Szent István történeti kutatásunkban. In: GLATZ FERENCKARDOS JÓZSEF szerk. Szent István és kora. Budapest, MTA Történettudományi Intézet. 18-22.

GYÖRFFY GYÖRGY 2001. Szent István király és a pécsváradi apátság kapcsolata. In: FÜZESI MiKLÓs szerk. Pécsvárad. Pécsvárad, Pécsvárad város Önkormányzata. 97-101.

HeMFN. 1. = Pelle BÉláNÉ szerk. 1970. Heves megye földrajzi nevei I. Az egri járás. A Magyar Nyelvtudományi Társaság Kiadványai 125. Budapest. 
HOFFMANN ISTVÁN-RÁCZ ANITA-TÓTH VALÉRIA 2018. Régi magyar helynévadás. A korai ómagyar kor helynevei mint a magyar nyelvtörténet forrásai. Budapest, Gondolat Kiadó.

Holler LÁSZLó 2009. Egy XIII. századi remetekápolna - Idegsÿt Beatae Elizabeth - lokalizálása. Nyelvészeti vizsgálatok a séd és kút szavak körében. Magyar Nyelv 105: 17-29.

HORGER ANTAL 1909. Udvarhely vármegye székely nyelvjárásának hangtani sajátságai (Második közlemény). Nyelvtudományi Közlemények 39: 383-417.

HORGER ANTAL 1912. Bolgár-török jövevényszavaink. Magyar Nyelv 8: 446-458.

HORVÁTH J. GYULA-TIMÁR GYÖRGY 1973. XVI. századi dikális konskripciók Baranya megyéről $(1542,1551,1564)$. In: SzITA LÁSzLó szerk. Baranyai helytörténetírás. A Baranya megyei Levéltár évkönyve 1972. Pécs, Baranya megyei Levéltár. 7-127.

KARA FERENC 1912. Az 11 hang történetéhez. Magyar Nyelvör 41: 221-222.

KENYHERCZ RÓBERT 2016. A középkori oklevelek átírási gyakorlatának nyelvtörténeti vonatkozásai. Helynévtörténeti Tanulmányok 12: 7-44.

KISS GERGELY 1999. A Pécsváradi bencés kolostor birtokainak és egyházjogi kiváltságainak biztosítása a 12-13. században. In: HOMONNAI SAROLTA-PITI FERENCTóTH ILDIKÓ szerk. Tanulmányok a középkori magyar történelemröl. Az I. Medievisztikai PhD konferencia elöadásai. Szeged, Szegedi Középkorász Mühely. 49-64.

KIsS LAJOS 1995. Földrajzi neveink nyelvi fejlödése. Nyelvtudományi Értekezések 139. Budapest, Akadémiai Kiadó.

KISS LAJOS 1999. Hegynevek a történelmi Magyarországon. In: KISS LAJOS, Történeti vizsgálatok a földrajzi nevek körében. Piliscsaba, Pázmány Péter Katolikus Egyetem, BTK. 117-132.

KMHsz. = HOFFMANN ISTVÁN szerk. 2005. Korai magyar helynévszótár 1000-1350. I. Abaúj-Csongrád vármegye. A Magyar Névarchívum Kiadványai 10. Debrecen, Debreceni Egyetem Magyar Nyelvtudományi Tanszéke.

KNIEZSA ISTVÁN 1943-1944/2001. Kelet-Magyarország helynevei. Budapest, Lucidus Kiadó.

KoCÁN BÉla 2020. Ugocsa vármegye helyneveinek történeti-etimológiai szótára. Debrecen, Kézirat.

KOROMPAY KLÁRA 2003. Helyesírás-történet. [Az ómagyar kor.] In: KISS JENÖPUSZTAI FERENC szerk. Magyar nyelvtörténet. Budapest, Osiris Kiadó. 279-300.

KOROMPAY KLÁRA 2018. Helyesírás-történet. In: KISS JENÖ-PUSZTAI FERENC szerk. A magyar nyelvtörténet kézikönyve. Budapest, Tinta Könyvkiadó. 83-98.

KRISTÓ GYULA 2000. Szent István pécsváradi okleveléről. In: PITI FERENC-SZABADOS GYÖRGY szerk. , Magyaroknak eleiröl”. Ünnepi tanulmányok a hatvan esztendős Makk Ferenc tiszteletére. Szeged, Szegedi Középkorász Mühely. 307-321.

LIGETI LAJOS 1986. A magyar nyelv török kapcsolatai a honfoglalás elött és az Árpád-korban. Budapest, Akadémiai Kiadó.

MNyA. = DEME LÁSZLÓ-IMRE SAMU szerk. 1968-1977. A magyar nyelvjárások atlasza I-VI. Budapest, Akadémiai Kiadó. 
MTsz. = SZINNYEI JóZSEF szerk. 1893-1901. Magyar tájszótár I-II. Budapest, Magyar Tudományos Akadémia.

MUNKÁCSI BERNÁT 1882. Török kölcsönszók. Magyar Nyelvőr 11: 56-61.

NÉMETH GYULA 1912. Nyelvünk régi török jövevényszavai. Magyar Nyelvőr 41: 452-455.

OklSz. = SZAMOTA ISTVÁN-ZOLNAI GYULA 1902-1906. Magyar oklevél-szótár. Pótlék a Magyar Nyelvtörténeti Szótárhoz. Budapest, Magyar Tudományos Akadémia.

K. PALlÓ MARGit 1959. Hungaro-Tschuwaschica. Ural-altaische Jahrbücher 31: 239-258.

ReSZegi Katalin 2011. Hegynevek a középkori Magyarországon. A Magyar Névarchívum Kiadványai 21. Debrecen, Debreceni Egyetemi Kiadó.

REUTER CAMILLO 1969-1970. Gyüjtés Baranya középkori településtörténeti adattárához. Janus Pannonius Múzeum Évkönyve 14-15: 133-154.

ŠMILAUER, VLADIMír 1970. Príručka slovanské Toponomastiky. Handbuch der slawischen Toponomastik. Praha, Academia.

SolYMOSI LÁsZLó 1998. Szőlőmủvelés Magyarországon a középkorban. A honfoglalástól a 14. századig. História 20/5-6: 17-20.

SOLYMOSI LÁSZLÓ 2012. Szőlőbirtok és oklevéladás a középkori Magyarországon. In: BARÁTH MAGDOLNA-MOLNÁR ANTAL szerk. A történettudomány szolgálatában. Tanulmányok a 70 éves Gecsényi Lajos tiszteletére. Budapest-Györ, Magyar Országos Levéltár. 311-323.

SÖRÖS PONGRÁC 1905. Pécsváradi bencés apátság. Katolikus Szemle 19: 862-881, 951-967.

SzaBÓ T. ATTILA 1942. Kalotaszeg helynevei 1. Adatok. Kolozsvár, Minerva Nyomda.

SzÖKE MELINDA 2015. A garamszentbenedeki apátság alapitólevelének nyelvtörténeti vizsgálata. A Magyar Névarchívum Kiadványai 33. Debrecen, Debreceni Egyetemi Kiadó.

SzŐKE MELINDA 2019. Szent István Pécsváradi oklevelének Sorlogys helynevéröl és ami körülötte lehetett. Névtani Értesitö 41: 91-106.

TESz. = A magyar nyelv történeti-etimológiai szótára I-III. Főszerk. BENKÖ LORÁND. Budapest, Akadémiai Kiadó, 1967-1976.

TMFN. = VÉGH JÓZSEF-ÖRDÖGH FERENC-PAPP LÁSZLÓ szerk. 1981. Tolna megye földrajzi nevei. Budapest, Akadémiai Kiadó.

TÓTH VAlÉRIa 2001a. Az Árpád-kori Abaúj és Bars vármegye helyneveinek történeti-etimológiai szótára. A Magyar Névarchívum Kiadványai 4. Debrecen, Debreceni Egyetem Magyar Nyelvtudományi Tanszék.

TÓTH VALÉRIA 2001b. Névrendszertani vizsgálatok a korai ómagyar korban. A Magyar Névarchívum Kiadványai 6. Debrecen, Debreceni Egyetem Magyar Nyelvtudományi Tanszék.

TÓTH VALÉRIA 2012. Etimológiai, hangtörténeti megjegyzések Anonymus egy személynevéhez. Magyar Nyelvjárások 50: 51-76.

ÚMTsz. = B. LŐRINCZY ÉVA főszerk. 1979-2010. Új magyar tájszótár I-V. Budapest, Akadémiai Kiadó. 
Vat. = Monumenta Vaticana historiam regni Hungariae illustrantia. Series I. Tom. I-IV. Budapestini, 1885-1891.

VIRÁGH RÓZSA 1931. Magyar helységnevek eredete. A magyar helynév-kutatás eredményei. Szeged, Szeged Városi Nyomda és Könyvkiadó Rt.

WOT. = RÓNA-TAS ANDRÁS-BERTA ÁRPÁD 2011. West Old Turkic. Turkic loanwords in Hungarian. Wiesbaden, Harrassowitz Verlag.

ZSILINSZKY ÉVA 2003. Szókészlettörténet. [Az ősmagyar kor.] In: KISS JENÖ-PUSZTAI FERENC szerk. Magyar nyelvtörténet. Budapest, Osiris Kiadó. 173-203.

\section{On the Scedluc Toponym of the Charter of Pécsvárad}

The Charter of Pécsvárad forged for the age of St. Stephen (1015) was probably recorded in the first half of the $13^{\text {th }}$ century, using the authentic $11^{\text {th }}$-century founding charter from the era of St. Stephen among other sources, along with the survey charter from the end of the century. These charters (the authentic founding charter and the survey charter) have not survived on their own, only as part of the forged charter. We know the oldest section in the founding charter, i.e., the $13^{\text {th }}$ century forged charter, from a document surviving from the $15^{\text {th }}$-century after multiple copies. We may date the Charter of Pécsvárad the following way: $+1015 /+1158$ [1220 k.]/1323/1403/PR.

We can use the Charter of Pécsvárad with an uncertain chronological status successfully as a source in historical linguistics if we analyze the records of the founding charter individually and in this process explore whether the specific data belong to the $11^{\text {th }}, 13^{\text {th }}$ or $15^{\text {th }}$ century chronological layer of the charter, i.e., whether they had been present already in the original authentic charter, or were added only later, at the time of forgery or when the charter was copied; we also need to examine which century the linguistic elements belong to based on their historical phonological and orthographic features.

Of the toponyms in the Founding Charter of Pécsvárad listing 41 settlements as donations, in my paper I analyze the Scedluc name, confirming that it may be identified as Szellö settlement in Baranya County today and that it derives from the szölö 'grape' plant name.

After concluding the comprehensive analysis of the name form from the perspectives of historical phonology and orthography, we have discovered several phenomena indicating the early $11^{\text {th }}$ century (the age of St. Stephen). This is a significant circumstance because on the one hand it supports the existence of the authentic charter from 1015, while, on the other hand, it also means that the Scedluc record of the Charter of Pécsvárad represents the earliest mention known so far of the szölö 'grape' plant name (which is a Chuvash type Old Turkic loan

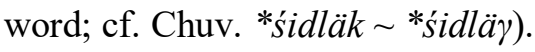

